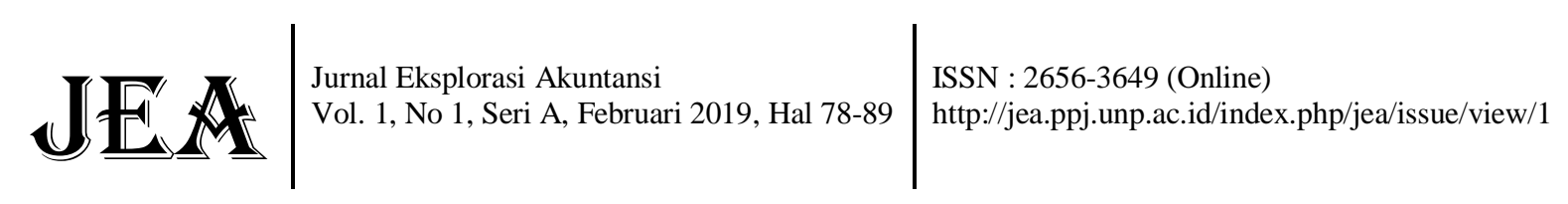

\title{
PENGARUH PENGUNGKAPAN MEDIA, KINERJA LINGKUNGAN DAN KEPEMILIKAN ASING TERHADAP PENGUNGKAPAN CORPORATE SOCIAL RESPONSBILITY
}

(Studi Empiris pada Perusahaan Pertambangan yang Terdaftar di Bursa Efek Indonesia Tahun 2014-2017)

\author{
Bima Dwi Darma ${ }^{1}$, Fefri Indra Arza $^{2}$, Halmawati ${ }^{3}$ \\ 1)Alumni Jurusan Akuntansi Fakultas Ekonomi Universitas Negeri Padang \\ 2,3) Jurusan Akuntansi Fakultas Ekonomi Universitas Negeri Padang \\ *Korespondensi: dharmabimadwi@gmail.com
}

\begin{abstract}
This study aims to see the effect of media exposure, environmental performance, and foreign ownership to corporate social responsibility disclosure. The population in this study are all mining companies listed on the Indonesia Stock Exchange (BEI) that is as many as 41 companies. The sample in this research use sampling technique purposive sampling counted 36 company. The analysis was done by using multiple regression model. The results of this study indicate that: (1) Media Exposure effect the disclosure of corporate social responsibility. (2) environmental peformance has no effect on corporate social responsibility disclosure. (3) foreign ownership has no effect on corporate social responsibility disclosure
\end{abstract}

Keywords: Media Exposure; Evironmental Peformance; Foreign Ownership; Corporate Social Responsibility Disclosure.

How to cite (APA $6^{\text {th }}$ style)

Darma, B.D., Arza, F.I., \& Halmawati. (2019). Pengaruh Pengungkapan Media, Kinerja Lingkungan Dan Kepemilikan Asing Terhadap Pengungkapan Corporate Social Responsbility (Studi Empiris pada Perusahaan Pertambangan yang Terdaftar di Bursa Efek Indonesia Tahun 2014-2017). Jurnal Eksplorasi Akuntansi, 1(1) Seri A, 78-89.

\section{PENDAHULUAN}

Perusahaan selalu berorientasi untuk mencapai keuntungan semaksimal mungkin, salah satu cara yang dilakukan perusahaan yaitu dengan membangun citra yang baik di masyarakat dengan memberikan perhatian kepada lingkungan atau tanggung jawab sosial, yang lebih dikenal dengan corporate social responsibility. Corporate social responsibility merupakan suatu konsep dalam organisasi yang memiliki berbagai tanggung jawab terhadap berbagai pemangku kepentingan seperti karyawan, pemegang saham, konsumen, masyarakat, dan lingkungan sekitar Respati dan Hadiprajitno (2012). Konsep CSR muncul dikarenakan terjadinya kerusakan yang diakibatkan oleh kegiatan operasional perusahaan, sehingga adanya tuntutan dan harapan dari masyarakat mengenai peran perusahaan terhadap lingkungan sekitar.

Perusahaan memiliki tujuan tersendiri dalam melakukan CSR, tujuannya adalah untuk memperoleh keunggulan kompetitif, untuk memenuhi ketentuan kontrak pinjaman dan memenuhi ekspektasimasyarakat, untuk melegitimasi tindakan perusahaan, dan untuk 
menarik investor (Deegan dan Blomquist, 2001; Hasnas, 1998; Ullman, 1985; Patten, 1992; dalam Sayekti dan Wondabio, 2007). Perusahaan juga mendapat keuntungan lain selain keunggulan kompetitif dari melakukan tanggung jawab sosialnyadiantaranya adalah meningkatkan citra positif perusahaan, akses modal, mempertahankan sumber daya manusia yang berkualitas dan mempermudah pengelolaan manajemen resiko (Daniri, 2008 dalam Karima, 2014).

Permasalahan-permasalahan sosial yang dihadapi oleh perusahaan di Indonesia terjadi karena lemahnya penegakan peraturan tentang tanggung jawab sosial perusahaan, misalnya tentang aturan ketenagakerjaan, pencemaran lingkungan, perimbangan bagi hasil suatu industri dalam era otonomi daerah Eka (2011). Pernyataan Standar Akuntansi Keuangan (PSAK) No.1 (revisi 2009) paragraf 12 menjelaskan pengungkapan CSR melalui laporan tahunan perusahaan kepada publik masih bersifat sukarela. Pengungkapan informasi sosial yang belum diwajibkan dalam PSAK menimbulkan praktik pengungkapkan informasi yang dilakukan oleh perusahaan umumnya bersifat voluntary (sukarela), unaudited (belum diaudit), dan unregulated (tidak dipengaruhi oleh peraturan tertentu) Eka (2011).

Pemerintah mengeluarkan peraturan yang terkait tanggung jawab sosial, yang diatur dalam Undang-Undang No. 40 tahun 2007 pasal 74 tentang tanggung jawab sosial dan lingkungan dan Peraturan Pemerintah No. 47 tahun 2012 pasal 2. Peraturan di atas menunjukkan bentuk kepedulian pemerintah terhadap masalah-masalah sosial yang merupakan bentuk pertanggung jawaban sosial perusahaan, tetapi belum ada standar mengenai seberapa banyak tanggung jawab sosial yang harus diungkap. Nurkhin (2009) menemukan bahwa tingkat pengungkapan tanggung jawab sosial di Indonesia tergolong masih rendah. Standar pengungkapan tanggung jawab sosial bagi dewan direksi perusahaan yang belum memiliki acuan menjadi salah satu penyebab dari hal tersebut.

Penelitian mengenai faktor-faktor yang mempengaruhi pengungkapan tanggung jawab sosial perusahaan juga berkembang dengan dimasukkannya variabel-variabel yang dianggap berpengaruh yaitu media. Media menyediakan informasi bagi perusahaan dan dapat pula sebagai alat publikasi serta sosialisasi yang digunakan oleh perusahaan Andriany, dkk (2017). Media telah banyak digunakan oleh perusahaan pada saat ini untuk menyediakan informasi. Bentuk-bentuk informasi yang bisa dikomunikasikan perusahaan melalui media salah satunya adalah kegiatan corporate social responsibility yang dilakukanperusahan. Pengkomunikasian CSR melalui media akan meningkatkan reputasi perusahaan di mata masyarakat.

Kinerja lingkungan sangat dipengaruhi oleh sejauh mana dorongan yang dilakukan perusahaan terhadap pengelolaan lingkungan. Kinerja lingkungan juga akan mencapai level yang tinggi apabila perusahaan secara proaktif melakukan berbagai tindakan manajemen lingkungan yang terkendali Oktalia (2014). Berdasarkan discretionary disclosure teori, pelaku lingkungan yang baik percaya bahwa dengan mengungkapkan performance mereka berarti menggambarkan good news bagi pelaku pasar. Oleh karena itu, perusahaan dengan kinerja lingkungan yang baik perlu mengungkapkan informasi lebih banyak dan mutu lingkungan yang lebih dibandingkan dengan perusahaan dengan kinerja lingkungan yang lebih buruk.

Kepemilikan asing dalam perusahaan merupakan pihak yang dianggap concern terhadap pengungkapan pertanggungjawaban sosial perusahaan. Investor asing memiliki kriteria yang bersifat sosial dalam setiap keputusan investasinya dan memiliki keterkaitan dengan keberlangsungan jangka panjang perusahaan Nilasari (2015). Perusahaan yang memiliki kepemilikan asing yang besar akan menungkapkan informasi corporate social responsibility lebih luas sehingga mempengaruhi pengungkapan.

Penelitian terhadap corporate social responsibility telah banyak dilakukan dan memiliki hasil yang beragam. Penelitian yang dilakukan oleh Respati (2015) mengatakan 
pengungkapan media memiliki pengaruh positif yang signifikan terhadap pengungkapan corporate social responsibility, sedangkan penelitian Nur (2012) mengatakan pengungkapan media tidak berpengaruh terhadap pengungkapan corporate social responsibility. Penelitian Wulandari (2017) dan Raharja (2012) mengatakan kinerja lingkungan berpengaruh terhadap pengungkapan corporate social responsibility, sedangkan penelitian Wijaya (2012) mengatakan kinerja lingkungan tidak berpengaruh secara signifikan terhadap pengungkapan corporate social responsibility. Penelitian Rustiarini (2011) mengatakan kepemilikan asing berpengaruh terhadap pengungkapan corporate social responsibility, sedangkan penelitian Karima (2014) mengatakan kepemilikan asing tidak berpengaruh terhadap pengungkapan corporate social responsibility.

Penelitian-penelitian empiris terdahulu dengan variabel dan hasil yang beragam, peneliti tertarik untuk menguji kembali tentang pengungkapan corporate social responsibility. Pada penelitian inipengungkapan corporate social responsibility diukur dengan merujuk standar pengungkapan corporate social responsibility oleh GRI (Global Reporting Initiative) (GRI-G4) dengan indikator pengungkapan sebanyak 91 item, sedangkan penelitian terdahulu banyak menggunakan (GRI-G3) yang mempunyai indikator sebanyak 71 item

\section{REVIU LITERATUR DAN HIPOTESIS \\ Teori Keagenan}

Prinsip utama pada teori agensi menyatakan adanya hubungan kerja antara pihak yang memberi wewenang (principal) yaitu investor, dengan pihak yang menerima wewenang (agensi) yaitu manajer dalam bentuk kontrak kerja sama yang disebut nexus of contract (Raharja, 2012). Teori agensi juga menjelaskan mengenai masalah asimetri informasi (information asymmetric).Asimetri informasiyaitu suatu keadaan dimana terdapat ketidakseimbangan perolehan informasi antara pihak manajemen sebagai penyedia informasi dengan pihak pemegang saham dan stakeholder pada umumnya sebagai pengguna informasi (Prasetio dan Suryono, 2016

Jensen dan Meckling (1976) menjelaskan adanya konflik kepentingan dalam hubungan keagenan. Konflik kepentingan ini terjadi dikarenakan perbedaan tujuan dari masing-masing pihak berdasarkan posisi dan kepentingan terhadap perusahaan. Manager sebagai agen, bertanggung jawab secara moral untuk mengoptimalkan keuntungan para pemilik, akan tetapi manager juga menginginkan untuk selalu memperoleh kompensasi sesuai kontrak.

\section{Teori Legitimasi}

Teori legitimasi dilandasi oleh "kontrak sosial" yang terjadi antara perusahaan dengan masyarakat dimana perusahaan beroperasi dan menggunakan sumber ekonomi. Teori legitimasi menjelaskan bahwa perusahaan melakukan kegiatan operasional dalam lingkungan eksternal yang berubah secara konstan dan perusahaan selalu berusaha meyakinkan bahwa perilaku mereka sesuai dengan batas-batas dan norma yang ada pada masyarakat luas (Michelon dan Parbonetti, 2010). Norma perusahaan selalu berubah mengikuti perubahan dari waktu ke waktu sehingga perusahaan harus mengikuti perkembangannya.

Kegiatan perusahaan harus memiliki batas-batas dan norma yang selaras dengan nilainilai masyarakat. Ketika nilai-nilai yang dianut perusahaan berbeda dengan batas-batas dan norma yang dijalankan masyarakat legitimasi perusahaan akan berada pada posisi terancam. Perbedaan antara nilai-nilai perusahaan dan nilai-nilai masyarakat sering disebut sebagai legitimacy gap dan dapat mempengaruhi kemampuan perusahaan untuk melanjutkan kegiatan usahanya (Ghozali dan Chariri, 2007). 


\section{Pengungkapan Corporate Social Responsibility}

TheWorld Business Council for Sustainable Development (WBCSD) dalam Rustiarini, (2011) mendefinisikan CSR atau Tanggung jawab Sosial Perusahaan, sebagai :

"Continuing commitment by business to be have ethically and contribute to economic development while improving the quality of life of the workface and their families as well as of the local community and society at large."

Pernyataan yang diungkapkan WBCSD tersebut merupakan sebuah bentuk komitmen di dalam dunia usaha untuk terus menerus bertindak secara etis, beroperasi secara legal dan berkontribusi untuk peningkatan ekonomi, bersamaan dengan peningkatan kualitas hidup dari karyawan dan keluarganya sekaligus juga peningkatan kualitas komunitas lokal dan masyarakat secara lebih luas.

John Elkington dalam Wibisono (2007) pada tahun 1997 melalui bukunya "Cannibals with Forks, the Triple Bottom Line of Twentieth Century Business" mengenalkan istilah triple bottom line. Elkington mengembangkan konsep triple bottom line dalam istilah economic prosperity, environmental quality dan social justice. Elkington memberi pandangan bahwa perusahaan yang ingin berkelanjutan haruslah memperhatikan "3P". Selain mengejar profit, perusahaan juga harus memperhatikan dan terlibat dalam pemenuhan kesejahteraan masyarakat (people) dan turut berkontribusi aktif dalam menjaga kelestarian lingkungan (planet).

\section{Pengungkapan Media}

Menurut Respati (2015) menyatakan bahwa pengungkapan media adalah cara perusahaan mengkomunikasikan identitas serta informasi mengenai kegiatan yang dilakukan oleh perusahaan dengan memanfaatkan media yang telah tersedia.Suatu perusahaan bisa mengkomunikasikan kegiatan-kegiatannya dengan memanfaatkan berbagai media, salah satu kegiatan yang bisa dikomunikasikan adalah pengungkapan lingkungan perusahaan.

\section{Kinerja Lingkungan}

Menurut Suratno, dkk (2006) mengatakan bahwa kinerja lingkungan adalah kinerja perusahaan dalam menciptakan lingkungan yang baik. Perusahaan memberikan perhatian terhadap lingkungan sebagai wujud tanggung jawab dan kepedulian perusahaan terhadap lingkungan. Hubungan antara kinerja lingkungan dengan teori legitimasi adalah kinerja lingkungan yang baik harus dimiliki oleh perusahaan sebagai upaya mewujudkan organisasi yang ramah lingkungan atau peduli terhadap lingkungan sekitar, sehingga dapat meningkatkan legitimasi perusahaan di mata masyarakat. Organisasi standar internasional mengungkapkan bahwa dalam pencapaian kinerja lingkungan yang baik, harus menerapkan sistem manajemen lingkungan yang baik pula.

Dasar hukum pelaksanaan PROPER adalah Keputusan Menteri Negara Lingkungan Hidup Nomor:127/MENLH/2002 tentang Program Penilaian Peringkat Kinerja Perusahaan dalam Pengelolaan Lingkungan (PROPER). Keputusan Menteri Negara Lingkungan Hidup, selanjutnya diperbaharui melalui penerbitan Keputusan Menteri Negara Lingkungan Hidup Nomor: 250 tahun 2004 tentang Perubahan atas Kepmen Nomor: 127/MENLH/2002tentang Program Penilaian Peringkat Kinerja Perusahaan dalam Pengelolaan Lingkungan Hidup.PROPER dapat dijadikan pilihan dalam mengukur kinerja lingkungan perusahaan yang ada di Indonesia. Informasi mengenai kinerja lingkungan perusahaan dikomunikasikan dengan menggunakan simbol warna untuk memudahkan penyerapan informasi oleh masyarakat. 


\section{Kepemilikan Asing}

Kepemilikan saham asing adalah jumlah saham yang dimiliki oleh pihak asing (luar negeri) baik oleh individu maupun lembaga terhadap saham perusahaan di Indonesia Rustiarini (2011). Kepemilikan asing dianggap sebagai pihak yang concern terhadap program corporatesocialresponsibility (CSR). Negara-negara di Eropa sangat memperhatikan isu sosial misalnya hak asasi manusia, pendidikan, tenaga kerja, dan lingkungan seperti efek rumah kaca, pembalakan liar, serta pencemaran air. Hal ini menjadikan perusahaan multinasional mulai mengubah perilaku mereka dalam beroperasi demi menjaga legitimasi dan reputasi perusahaan. Bank-bank di Eropa juga menerapkan kebijakan dalam pemberian pinjaman hanya kepada perusahaan yang mengimplementasikan CSR dengan baik.

\section{Pengembangan Hipotesis}

\section{Hubungan Pengungkapan Media terhadap Pengungkapan Corporate Social Responsibiliy}

Media merupakan pusat perhatian masyarakat luas mengenai sebuah perusahaan. Pengkomunikasian kegiatan corporate social responsibility melalui media perusahaan akan meningkatkan reputasi perusahaan di mata masyarakat hal inisesuai dengan teori legitimasi yang menjelaskan bahwa perusahaan beroperasi dalam lingkungan eksternal yang berubah secara konstan dan perusahaan berusaha meyakinkan bahwa perilaku mereka sesuai dengan batas-batas dan norma masyarakat. Perusahaan dalam hal ini dapat mengungkapkan aktivitas corporate social responsibility melalui berbagai media yang ada.Ratnasari (2012) menyatakan bahwa media internet (website) merupakan media yang efektif dengan didukung oleh para pemakai internet yang mulai meningkat pada saat ini. Harapan pengungkapan CSR perusahaan melalui media internet adalah agar masyarakat mudah mengakses aktivitas sosial yang dilakukan oleh perusahaan melalui website perusahaan.

Penelitian oleh Respati (2015) yang meneliti pada perusahaan manufaktur yang terdaftar di BEI tahun 2014 menjelaskan bahwa pengungkapan media memiliki pengaruh positif yang signifikan terhadap pengungkapan corporate social responsibility, hasil penelitian tersebut didukung oleh Andriyani, dkk (2017) yang meneliti pada perusahaan BUMN di Indonesia tahun 2014-2015 menjelaskan secara simultan pengungkapan media memilki pengaruh signifikan terhadap pengungkapan corporate social responsibiliy. Berdasarkan uraian di atas, maka dapat disimpulkan hipotesis pertama adalah:

$\mathbf{H}_{1}$ : Pengungkapan media berpengaruh positif terhadap pengungkapan Corporate Social Responsibiliy.

\section{Hubungan Kinerja Lingkungan terhadap Pengungkapan Corporate Social Responsibiliy}

Menurut Suratno, dkk (2006) mengatakan bahwa kinerja lingkungan adalah kinerja perusahaan dalam menciptakan lingkungan yang baik.Menurut Verrecchia (1983) dalam Rakhiemah dan Agustia (2009), dengan discretionary disclosure teorinya mengatakan pelaku lingkungan yang baik percaya bahwa dengan mengungkapkan kinerja lingkungan mereka berarti menggambarkan good news bagi pelaku pasar. Jadi, perusahan dengan kinerja lingkungan yang baik akan mengungkapkan infomasi tentang lingkungan lebih luas.

Penelitian oleh Raharja (2012) dan Wulandari (2015) menjelaskan bahwa kinerja lingkungan berpengaruh positif terhadap pengungkapan corporate social responsibiliy. Berdasarkan uraian di atas, maka dapat disimpulkan hipotesis kedua adalah:

$\mathbf{H}_{2}$ : Kinerja lingkungan berpengaruh positif terhadap pengungkapan Corporate Social Responsibiliy 


\section{Hubungan Kepemilikan Asing terhadap Pengungkapan Corporate Social Responsibiliy}

Asimetri informasi yang terjadi antara perusahaan dan investor asing dalam pengungkapan CSR disebabkan karena adanya hambatan perbedaan bahasa dan geografis. Investor asing sebagai pihak yang concern terhadap program CSR cenderung lebih ketat dalam pengawasan operasional perusahaannya. Investor asing menuntut perusahaan untuk bekerja keras agar investasi yang mereka lakukan dapat memberikan pengembalian yang besar, sehingga investor asing membutuhkan informasi yang lebih efisien untuk memenuhi kebutuhannya. Kepemilikan asing termasuk dalam salah satu aspek corporategovernance sebagai mekanisme kontrol dalam mengurangi konflik kepentingan. Perusahaan dengan kepemilikan saham asing yang besar akan terdorong untuk melaporkan atau mengungkapkan informasinya secara sukarela dan lebih luas (Huafang dan Jianguo, 2007 dalam Rustiarini, 2011).

Penelitian oleh Rustiarini (2011) menjelaskan bahwa secara parsial dan simultan kepemilikan asing berpengaruh secara signifikan terhadap pengungkapan corporate social responsibiliy. Berdasarkan uraian di atas, maka dapat disimpulkan hipotesis kedua adalah:

H3: Kepemilikan asing berpengaruh positif terhadap pengungkapan Corporate Social Responsibiliy

\section{METODE PENELITIAN}

Jenis penelitian ini adalah penelitian kausatif, yaitu menganalisis bagaimana pengaruh antara variabel yang satu dengan variabel yang lainnya. Populasi dalam penelitian ini adalah seluruh perusahaan pertambangan yang terdaftar di Bursa Efek Indonesia (BEI) dari tahun 2014-2017 yang berjumlah 41 perusahaan dengan 36 sampel. Teknik pengambilan sampel pada penelitian ini menggunakan teknik purposive sampling yaitu teknik pengambilan sampel berdasarkan kriteria-kriteria tertentu. Kriteria pengambilan sampel sebagai berikut: 1) Perusahaan pertambangan yang listing di BEI selama periode pengamatan 2014-2017, 2) mempublikasikan laporan tahunan (annual report) secara lengkap, dan 3) Perusahaan pertambangan yang terdafatar PROPER sacara berturut-turut tahun 2014-2017.

\section{Variabel Penelitian dan Pengukuran Variabel dependen}

Varibel dependen yang digunakan dalam penelitian ini adalah pengungkapan corporate social responsibiliy. Pengukuran variabel ini mennggunakan CSRI yaitu dengan melihat indikator Global Reporting Initiatives (GRI) (GRI-G4). Dalam standar GRI, indikator kinerja dibagi menjadi tiga komponen utama, yaitu ekonomi, lingkungan hidup dan sosial yang mencakup hak asasi manusia, praktek ketenagakerjaan dan lingkungan kerja, tanggung jawab produk dan masyarakat, dengan total indikator mencapai 91 item.

\section{Variabel Independen}

\section{Pengungkapan Media}

Pengungkapan media adalah cara perusahaan cara perusahaan mengkomunikasikan identitas serta informasi mengenai kegiatan yang dilakukan oleh perusahaan dengan memanfaatkan media yang telah tersedia. Penelitian ini mengukur pengungkapan media dengan variabel dummy, yaitu dengan memberikan nilai 1 untuk perusahaan yang mengungkapkan kegiatan CSR di dalam web perusahaan dan 0 untuk perusahaan yang tidak mengungkapkan kegiatan CSR di dalam web perusahaan (Rhespati, 2015). 


\section{Kinerja Lingkungan}

Kinerja Lingkungan yang baik dapat tercipta jika perusahaan memperhatikan lingkungan sekitar perusahaan. Kinerja lingkungan di ukur dengan menggunakan Program Penilaian Peringkat Kinerja perusahaan dalam pengelolaan lingkungan hidup yang diadakan oleh Kementrian Lingkungan Hidup. Pelaksanaan PROPER dilakukan berdasarkan Keputusan Menteri Negara Lingkungan Hidup Nomor 7 tahun 2008 tentang Program Penilaian Peringkat Kinerja Perusahaan dalam Pengelolaan Lingkungan Hidup. Kinerja perusahaan dalam Proper ini dinilai berdasarkan 5 peringkat warna. Peringkat secara berurutan dikatergorikan dari yang terbaik, EMAS, HIJAU, BIRU, MERAH, sampai ke yang terburuk, HITAM. Pengukuran ini merujuk pada penelitian yang dilakukan oleh Oktalia (2014), Dalam penelitian ini pengukuran dilakukan dengan memberikan skor pada setiap warna yang ada dalam penliaian PROPER, yaitu:

Emas : Sangat-sangat baik, skor $=5$

Hijau : Sangat baik, skor $=4$

Biru $\quad:$ Baik, skor $=3$

Merah : Buruk, skor $=2$

Hitam : Sangat buruk, skor $=1$

\section{Kepemilikan Asing}

Kepemilikan asing adalah jumlah saham yang dimiliki oleh pihak asing (luar negeri) baik oleh individu maupun lembaga terhadap saham perusahaan di Indonesia. Kepemilikan asing diukur dari rasio dari jumlah kepemilikan saham asing terhadap total saham perusahaan (Rustiarini, 2011).

\section{Teknik Analisis Data}

Analisis digunakan meliputi statistik deskriptif penelitian ini bertujuan untuk menginterpretasikan nilai rata-rata, median, standar deviasi, nilai maksimum, dan nilai minimum dari masing-masing variabel penelitian.. Pengujian hipotesis menggunakan analisis regresi berganda dengan bantuan program SPSS.

\section{HASIL DAN PEMBAHASAN}

Bagian ini menguraikan hasil pengujian pengaruh pengungkpan media, kinerja lingkungan dan kepemilikan asing terhadap pengungkapan corporate social responsibility

\section{Statistik Deskriptif}

Supaya lebih mudah dalam melihat gambaran secara umum mengenai variabel yang diteliti dan setelah melalui proses pengolahan dengan menggunakan SPSS 25, berikut tabel yang menjelaskan variabel secara statistik.

Tabel 1

\begin{tabular}{l|r|r|r|r|r}
\hline & N & \multicolumn{1}{|c}{ Min } & Max & \multicolumn{1}{c}{ Mean } & Std. Deviation \\
\hline Csri & 36 & .01 & .96 & .2061 & .27667 \\
\hline Pm & 36 & .00 & 1.00 & .4167 & .50000 \\
\hline KI & 36 & 2.00 & 5.00 & 3.8333 & .94112 \\
\hline Ka & 36 & .00 & .97 & .3739 & .35637 \\
\hline Valid N (listwise) & 36 & & & & \\
\hline
\end{tabular}

Sumber: Olahan Data SPSS 25 


\section{Uji Kelayakan Model}

\section{a. Koefisien Determinasi (Adjusted $\boldsymbol{R}^{2}$ )}

Berikut merupakan nilai adjusted $\mathrm{R}$ square pada penelitian ini yang dapat dilihat pada tabel berikut:

Tabel 2

\begin{tabular}{|c|c|c|}
\hline \multicolumn{3}{|c|}{ - } \\
\hline Model & $\begin{array}{l}\text { Adjusted R } \\
\text { Square }\end{array}$ & Durbin-Watson \\
\hline 1 & .327 & .828 \\
\hline
\end{tabular}

Sumber: Olahan Data SPSS 25

Berdasarkan di atas dapat dilihat bahwa nilai adjusted $\mathrm{R}$ square adalah 0,327. Hal ini menunjukkan bahwa kontribusi variabel independen terhadap variabel dependen adalah sebesar $32,7 \% \%$ sedangkan $67,3 \% \%$ ditentukan oleh faktor lain diluar penelitian.

\section{b. Uji F}

Adapun hasil uji F pada penelitian ini dapat dilihat pada tabel berikut:

Tabel 3

\begin{tabular}{ll|l|l} 
Model & & F & Sig. \\
\hline 1 & Regression & 6.677 & $.001^{\mathrm{b}}$ \\
\cline { 2 - 4 } & Residual & & \\
\cline { 2 - 4 } & Total & & \\
\hline
\end{tabular}

Sumber: Olahan Data SPSS 25

Berdasarkan hasil uji $\mathrm{F}$ statistik diatas dapat dilihat bahwa nilai $\mathrm{F}_{\text {hitung }}$ adalah sebesar 6,677 dan nilai signifikan sebesar 0,001 . Hal ini menunjukkan nilai $F_{\text {hitung }}(6,677)>F_{\text {tabel }}$ $(2,901)$ dan sig $(0,001)<\alpha(0,05)$, sehingga dapat disimpulkan bahwa variable independen berpengaruh signifikan secara simultan (bersama-sama) terhadap variabel dependen serta persamaan regresi yang digunakan dalam penelitian ini dapat diandalkan atau model sudah fix.

\section{Analisis Regresi Berganda}

\begin{tabular}{|c|c|c|c|c|c|}
\hline & & $\begin{array}{r}\text { Ta } \\
\text { Unstand } \\
\text { Coeffic }\end{array}$ & $\begin{array}{l}\text { el } 4 \\
\text { lized } \\
\text { hts }\end{array}$ & & \\
\hline Model & & B & $\begin{array}{l}\text { Std. } \\
\text { Error }\end{array}$ & $\mathrm{t}$ & Sig. \\
\hline 1 & $C$ & .014 & .247 & .055 & .957 \\
\hline & pm & .282 & .094 & 2.993 & .005 \\
\hline & $\mathrm{kl}$ & .027 & .059 & .464 & .646 \\
\hline & ka & -.078 & .138 & -.565 & .576 \\
\hline
\end{tabular}

Sumber: Olahan Data SPSS 25

Berdasarkan pengolahan data statistik pada tabel 4, diperoleh penurunan regresi linear berganda sebagai berikut:

csri $=0,014+0,282 \mathrm{pm}+0,027 \mathrm{kl}-0,078 \mathrm{ka}$

\section{Uji T (Hipotesis)}

\section{Pengujian Hipotesis Pertama $\left(\mathbf{H}_{1}\right)$}

Variabel pengungkapan media pada tabel 7 memiliki nilai $t_{\text {hitung }} 2,993>t_{\text {tabel }} 2,028$ dan nilai sig $(0,005)<\alpha(0,05)$ serta nilai koefisien $\beta$ sebesar 0,282 . Hal ini menunjukkan bahwa variabel pengungkapan media berpengaruh positif terhadap pengungkapan corporate social responsbility, sehingga dapat disimpulkan bahwa Hipotesis 1 diterima. 


\section{Pengujian Hipotesis Kedua $\left(\mathrm{H}_{2}\right)$}

Variabel kinerja lingkungan pada tabel 7 memiliki nilai $t_{\text {hitung }} 0,464<t_{\text {tabel }} 2,028$ dan nilai sig $(0,646)>\alpha(0,05)$ serta nilai koefisien $\beta$ sebesar 0,027 . Hal ini menunjukkan bahwa variabel kinerja lingkungan tidak berpengaruh terhadap pengungkapan corporate social responsbility, sehingga dapat disimpulkan bahwa Hipotesis 2 ditolak.

\section{Pengujian Hipotesis Ketiga $\left(\mathbf{H}_{3}\right)$}

Variabel kepemilikan asing pada tabel 7 memiliki nilai $t_{\text {hitung }}-0,565<\mathrm{t}_{\text {tabel }} 2,028$ dan nilai sig $(0,576)>\alpha(0,05)$ serta nilai koefisien $\beta$ sebesar $-0,078$. Hal ini menunjukkan bahwa variabel kepemilikan asing tidak berpengaruh terhadap pengungkapan corporate social responsbility, sehingga dapat disimpulkan bahwa Hipotesis 3 ditolak.

\section{Pembahasan}

\section{Pengaruh pengungkapan media terhadap pengungkapan corporate social responsibility}

Berdasarkan hasil analisis statistik dalam penelitian ini perusahaan pertambangan, ditemukan bahwa pengungkapan media berpengaruh positif terhadap pengungkapan corporate social responsbility. Hasil ini dapat diartikan bahwa perusahaan yang menyajikan informasi kegiatan CSR dalam website resminya akan mengungkapkan CSR yang lebih luas. Hasil penelitian memberikan bukti empiris bahwa perusahaan yang mengungkapkan corporate social responsbility di website perusahaan akan cenderung mengungkapkan corporate social responsbility secara lebih luas dalam laporan tahunandan laporan keberlanjutan perusahaan.

Alasan yang mendasarinya adalah perusahaan yang mengungkapkan kegiatan sosialnya pada website perusahaan dinilai terbuka terhadap masyarakat luas karena dapat diakses oleh masyarakat secara umum untuk legitimasi perusahaan. Penyampaian kegiatan sosial perusahaan mampu untuk memberikan informasi yang cukup dan lugas kepada masyarakat umum yang masih awam, jika dibandingkan dengan memahami laporan tahunan perusahaan. Sedangkan laporan tahunan perusahaan akan mampu memberikan informasi yang lebih detail terkait kegiatan sosial yang dilakukan selama periode tersebut yang sifatnya lebih spesifik untuk para pemangku kepentingan di perusahaan. Jadi, pengungkapan CSR yang ada pada laporan tahunan perusahaan lebih detail dan spesifik. Hasil penelitian ini relevan dengan penelitian yang dilakukan oleh Diny dkk (2017)dan Rheza \& Paulus (2015) dimana pengungkapan media berpengaruh positif terhadap pengungkapan corporate social responsibility.

\section{Pengaruh kinerja lingkungan terhadap pengungkapan corporate social responsibility}

Berdasarkan hasil analisis statistik dalam penelitian ini perusahaan pertambangan, ditemukan bahwa kinerja lingkungan tidak berpengaruh terhadap pengungkapan corporate social responsbility. Hasil ini dapat diartikan bahwa pengungkapan corporate social responsibility yang dilakukan perusahaan tidak dipengaruhi oleh penilaian PROPER yang diikuti perusahaan yang menjadi pengukuran untuk kinerja lingkungan pada penelitian ini.

Penilaian PROPER merupakan suatu legitimasi masyarakat kepada perusahaan yang diwakili pemerintah yaitu kementerian lingkungan hidup. Penilaian PROPER memberikan gambaran kondisi tentang dampak lingkungan yang disebabkan oleh kegiatan operasional perusahaan. Perusahaan yang telah berpartisipasi dalam penilaian PROPER berdasarkan kriteria-kriteria penilaian yang telah ditetapkan, mendapatkan legitimasi masyarakat yang menjadi salah satu tujuan perusahaan. Kegiatan PROPER yang telah diikuti oleh perusahaan membuat perusahaan tidak perlu mengungkapkan kegiatan CSR secara terperinci lagi pada laporan tahunan. Hasil penelitian ini relevan dengan penelitian yang dilakukan oleh Wijaya 
(2012) dimana kinerja lingungan tidak berpengaruh terhadap pengungkapan corporate social responsibility.

\section{Pengaruh kepemilikan asing terhadap pengungkapan corporate social responsibility}

Berdasarkan hasil analisis statistik dalam penelitian ini perusahaan pertambangan, ditemukan bahwa kepemilikan asing tidak berpengaruh terhadap pengungkapan corporate social responsbility. Hasil ini dapat diartikan bahwa pengungkapan corporate social responsibility yang dilakukan perusahaan tidak dipengaruhi oleh jumlah saham yang dimilki asing dalam perusahaan.

Tidak signifikannya hasil penelitian ini disebabkan karena rata-rata perusahaan sampel lebih didominasi oleh perusahaan yang tidak memiliki kepemilikan saham asing yang besar tetapi pengungkapan CSR sudah cukup efektif terlaksana sehingga tidak terdapat hubungan yang signifikan antara jumlah presentase kepemilikan saham asing terhadap luas atau tidaknya pengungkapan corporate social responsibility (Maulidra, 2015:21). Kepemilikan asing dalam perusahaan di Indonesia tidak ada hubungannya dengan pengungkapan CSR yang dilakukan perusahaan, hal ini terjadi karena kemungkinan kepemilikan asing pada perusahaan di Indonesia secara umum belum mempedulikan masalah lingkungan dan sosial sebagai isu kritis yang harus secara luas untuk diungkapkan dalam laporan tahunan dan laporan sustainability. Dengan demikian dapat disimpulkan besar atau kecilnya presentase kepemilikan asing di suatu perusahaan tidak dapat mempengaruhi pengungkapan tanggung jawab sosial yang dilakukan oleh perusahaan. Hasil penelitian ini relevan dengan penelitian yang dilakukan oleh Karisma (2014)dimana kepemilikan asing tidak berpengaruh terhadap pengungkapan corporate social responsibility.

\section{PENUTUP}

\section{Kesimpulan}

Penelitian ini bertujuan untuk melihat seberapa besar pengaruh pengungkapan media, kinerja lingkungan dan kepemilikan asing terhadappengungkapan corporate social responsibility pada perusahaan pertambangan yang terdaftar di Bursa Efek Indonesia (BEI) pada tahun 2014 sampai tahun 2017. Berdasarkan hasil temuan penelitian dan pengujian hipotesis yang diajukan sebelumnya dapat disimpulkan bahwa:

1. Pengungkapan media berpengaruh positif terhadap luas pengungkapan corporate social responsibility.

2. Kinerja lingkungan tidak berpengaruh signifikan terhadap luas pengungkapan corporate social responsibility.

3. Kepemilikan asing tidak berpengaruh signifikan terhadap luas pengungkapan corporate social responsibility.

\section{Keterbatasan}

Meskipun peneliti telah berusaha merancang dan mengembangkan penelitian sedemikian rupa, namun masih terdapat beberapa keterbatasan dalam penelitian ini yang masih perlu revisi penelitian selanjutnya, antara lain:

1. Penelitian ini memiliki keterbatasan terdapatnya unsur subjektivitas dalam menentukan indeks pengungkapan corporate social responsibility. Hal ini dikarenakan tidak adanya ketentuan baku yang dapat dijadikan acuan.

2. Nilai adjustedR-Square yaitu sebesar $32,7 \%$ menunjukkan bahwa masih banyak variabel lain yang memiliki kontribusi yang besar dalam mempengaruhi luas pengungkapan sukarela pada laporan tahunan perusahaan.

3. Penelitian sampel dalam penelitian ini adalah purposive sampling. Keunggulan metode ini adalah peneliti dapat memilih sampel yang tepat, sehingga peneliti akan memperoleh 
data yang memenuhi kriteria untuk diuji. Namun, penggunaan metode purposive sampling berakibat pada kurangnya kemampuan generalisasi dari hasil penelitian.

\section{Saran}

Berdasarkan keterbatasan yang ada pada penelitian ini, maka saran dari penelitian ini yaitu:

1. Bagi penelitian selanjutnya yang tertarik untuk meneliti judul yang sama sebaiknya mempertimbangkan dan mencari variabel independen lain yang bepengaruh terhadap luas pengungkapan CSR.

2. Melakukan penelitian tidak hanya menggunakan sampel dari perusahaan manufaktur saja, tetapi menggunakan seluruh perusahaan yang terdaftar di BEI.

\section{DAFTAR PUSTAKA}

Andriany, dini, Willy Sri Yulandari dan Djusminar Zutilisna. 2017. Pengaruh Ukuran Perusahaan, Profitabilitas Leverage dan Pengungkapan Media terhadap Pengungkapan Corporate Social Responsbility. ISSN: 2355-9357. Vol. 4 No. 3 page 2723

Eka Nanda Putra. (2011). Pengaruh Fahmi, Faisal Nur, 2015 Pengaruh Ukuran Dewan Komisaris, Profitabilitas, Media Exposure Dan Umur Perusahaan Pengungkapan Corporate Social ResponsibilityJ,'Skripsi, Universitas Negeri Semarang.

Ghozali, Imam dan A. Chariri, 2007, Teori Akuntansi, Badan Penerbit Universitas Diponegoro, Semarang.

Jensen, M. C. \& W. Meckling. 1976. "The Teory of the Firm: Managerial Behavior, Agency Costs and Ownership Structure”. Journal of Financial Economics 3. Hlm305-360.

Karima, Naila. 2014. Pengaruh Kepemilikan Manajerial, Kepemilikan Institusional, dan Kepemilikan Asing terhadap Pengungkapantanggung Jawab Sosial Perusahaan. ISSN 0854-198. Widya Warta No. 02Tahun XXXVIII/Juli2014.

Keputusan Menteri Negara Lingkungan Hidup Nomor: 250 tahun 2004 tentang Perubahan atas Kepmen Nomor: 127/MENLH/2002 tentang Program Penilaian Peringkat Kinerja Perusahaan dalam Pengelolaan Lingkungan Hidup.

Michelon, Giovanna dan Parbonetti, Antonio. 2010. "The Effect of Corporate Governance on Sustainability Disclosure". Dalam Springer Science \& Business Media 14 September 2010.

Nilasari, Ervika. 2015. Pengaruh Profitabilitas, Kepemilikan Institusional, Kepemilikan Asing terhadap CSR Disclosure pada Perusahaan Pertambangan yang melakukan Listing di BEI tahun2010-2012

Nur Marzully dan Denies Priantinah. 2012. Analisis Faktor-Faktor Yang Mempengaruhi Pengungkapan Corporate Social Responsibility di Indonesia pada Perusahaan Berkategori High Profile yang Listing Di Bursa Efek Indonesia. Jurnal Nominal. Vol. 1 No.1

Nurkhin, Ahmad. 2009. Corporate Governance dan Profitabilitas, Pengaruhnya Terhadap Pengungkapan CSR Sosial Perusahaan. Jurnal Dinamika Akuntansi. Vol.2 No.1.4655.

Oktalia, D. (2014). Pengaruh Kinerja Lingkungan dan Profitabilitas Terhadap Corporate Social Responsibility Disclosure dalam Laporan Tahunan Perusahaan, 1-26.

Peraturan Pemerintah No. 47 tahun 2012 pasal 2

Pernyataan Standar Akuntansi Keuangan (PSAK) No. 1 paragraf 9 tentang pengungkapan dampak lingkungan 
Prasetio, Djoko Adi \& Suryono, Bambang. 2016. Pengaruh Profitabilitas, Free Cash Flow, Investment Opportunity Set terhadap Dividend Payout Ratio. Jurnal Ilmu dan Riset Akuntansi. Vol 5, No 1. Hlm1-18.

Raharja, V. A. P. (2012). Pengaruh Kinerja Lingkungan Dan Karakteristik Perusahaan Terhadap Corporate Social Responsibility (Csr) Disclosure (Studi Empiris Pada Perusahaan Manufaktur Yang. Accounting, 1(2), 1-12.

Rakhiemah, Aldilla Noor dan Dian Agustia. (2009). Pengaruh Kinerja Lingkungan terhadap Corporate Social Responsibility (CSR) Disclosure dan Kinerja Finansial Perusahaan Manufaktur yang Terdaftar di Bursa Efek Indonesia. Universitas Airlangga, Surabaya.

Respati, Dwi Rheza dan Paulus Basuki Hadiprajitno. 2015. Analisis Pengaruh Profitabilitas, Leverage, Ukuran Perusahaan, Tipe Industri dan Pengungkapan Media terhadap Pengungkapan CSR. Vol. 4 No. 4. 1-11

Rustiarini, N. W, 2011, Pengaruh Struktur Kepemilkan Saham pada Pengungkapan Corporate Social Responsibility. Jurusan Akuntansi, Vol.6, No.1, Januari 2011.

Sayekti, Yosefa dan Ludovicus Sensi Wondabio. 2007. Pengaruh CSR Disclosure terhadap Earning Response Coefficient. Simposium Nasional Akuntansi IX, Makasar.

Suratno, Ignatius Bondan, dkk. 2006. Pengaruh Environmental Performance terhadap Environmental Disclosure dan Economic Performance (Studi Empiris pada Perusahaan Manufaktur yang Terdaftar di Bursa Efek Jakarta Periode 2001-2004). Simposium Nasional Akuntansi IX. Padang.

Undang-undang No 40 Tahun 2007 pasal 74

Wibisono, Y. 2007. Membedah Konsep Dan Aplikasi CSR. Gresik: Fascho Publishing.

Wijaya, Maria. (2012). Faktor-Faktor Yang Mempengaruhi Pengungkapan Tanggung Jawab Sosial Pada Perusahaan Manufaktur Yangterdaftar Di Bursa Efek Indonesia. Jurnal Ilmiah Mahasiswa Akuntansi, 1(1), 26-30.

Wulandari, Andriyani Kusuma dan Abriyani Puspanigsih. 2017. Analisis Determinan Corporate Social Responsibility (Csr) Disclosure di Indonesia. Simposium Nasional Akuntansi XX, Jember, 2017

www.csr-asia.com diakses tanggal 18 April 2018

www.globalreporting.org \diakses tanggal 5 juni 2018 